DOI https://doi.org/10.18551/rjoas.2018-05.03

\title{
EMPLOYEES' PERFORMANCE BEFORE AND AFTER E-GOVERNMENT IMPLEMENTATION: A CASE STUDY OF THE LOCAL BOARD FOR FINANCE AND ASSET MANAGEMENT IN TANGGAMUS REGENCY OF INDONESIA
}

\author{
Yulianto \\ Public Administration Department, Lampung University, Indonesia \\ Suripto \\ Business Administration Department, Lampung University, Indonesia \\ *E-mail: yulianto4761@gmail.com
}

\begin{abstract}
This study aims to examine the difference between the performance of employees before and after e-government implementation. This research used quantitative approach with questionnaires distributed to 36 employees from the total population of 57 people at the Local Board for Finance and Asset Management in Tanggamus Regency. The results were tested using stepwise method with 3 variables of employee performance. The results show that there is significant difference in work quantity and on time working performance before and after e-government implementation; while, the quality of work does not show any significant difference. Considering Wilk's Lambda, there is significant difference on the performance of employees before and after e-government implementation. This research suggests that there is the need to improve Standard Operational Procedures related to the process of monitoring and improvement of the quality of work. This research also recommends that e-government can be implemented in all local institutions, especially for public services.
\end{abstract}

\section{KEY WORDS}

E-government, employee, performance, working performance, public service.

Good governance practice is expected to affect better public services. However, to implement the good governance, the government needs to improve its systems and processes (Basu, 2004; Bakry, 2003). In the context of Indonesia, Presidential Instruction number 3, year 2003 on National Policies and Strategies on the Development of EGovernment administers all Governors and Regents/Mayors at local government to take the importance steps in accordance with their respective duties, functions and authorities in order to develop and implement e-government (see Foley and Alfonso, 2009; Yildiz, 2007; Moon, 2000).

In the implementation of e-government, the role of employees in each institution cannot be avoided (Burn and Robins, 2003). There might be a correlation between the application of e-government and the performance of employees in the government institutions (Fagan, 2006; Kraemer and King, 2006). In this case, employees' performance becomes the key for e-government implementation. This is relevant with the concept of 'government to employees' where ultimately, e-government application is intended to improve the performance and welfare of employees who work for government institutions as public servants (Meijer, 2007; Indrajit, 2006). Thus the argument is that there is a link between egovernment implementation on the performance of government service to public (Schuppan, 2009; Aimee and Carol 2004). In sum, the performance of government's employees is the subject of the public governance process itself (Taylor and Lips, 2008 ; Koh and Prybutok, 2003).

Implementing e-government, of course is not only waiting for the readiness of all employees and the community in understanding and using technology, but also through a good planning (see Gronlund, 2005; Gronlund and Horan, 2005; Laye and Lee, 2001). The 
government has begun to implement the e-government initiatives in a very simple way. The Local Board for Finance and Asset Management at Tanggamus Regency has implemented Regional Management of Information System Application (SIMDA) for the budget seeking process. The Local Board for Finance and Asset Management at Tanggamus Regency is an autonomous institution led by a Head of the Board, established based on Regional Regulation Number 06, Year 2008. The function of the board is to implement the local leaders' duties. Thus, the Governor or Mayor/Regent has a direct control to the Head of the Board though local secretary. The implementation of e-government will help the government in improving its public services (Adegboyega, et al, 2004). According to Dharma (2003: 355), there are 3 dimensions of performance. They are the quantity of work, quality of work and timeliness/on time performance. Thus, it is interesting to see the difference in employee performance before and after e-government implementation through those three dimensions of performance.

\section{METHODS OF RESEARCH}

This study employed a quantitative approach since in this study the relationship between variables are causal and the aim of this study is to test the hypothesis among variables of performance. According Creswell (2014), data collection can be done through using research instruments, quantitative/statistical data in order to test the hypothesis that has been set out and to test the relationship between variables which are causal to the object of the study. The type of this study is explanatory research, as Creswell, (2014) said that explanatory study is the study to obtain data from a particular place through questionnaires as primary data.

Population is a generalization area which consists of objects or subjects that have certain qualities and characteristics set by the researchers to be studied and finally to be drawn of conclusions (Creswell, 2014). The population in this study is employees in the Local Board for Finance and Asset Management in Tanggamus Regency which is 57 people in total. However, the number of sample in this study is determined based on Slovin approach, with 36 respondents. Validity and reliability tests with the questionnaire as the main data were conducted. Descriptive statistics and Discriminant Analysis were employed.

\section{RESULTS OF STUDY}

Based on the data obtained from frequency distribution method, it can be concluded that generally, there is a positive effect on e-government implementation in the performance of employees at the Local Board for Finance and Asset Management at Tanggamus Regency in all variables which had been set out: the quantity of work, quality of work and on time working schedule. However, there is still the need to know whether all variables provide a significant difference or not. Thus, discriminant analysis method was used to examine the significant effects of the variables. Through the matrix of equality test, it is found that there is 95\% of confidence level. Groups, 1 and 2, have similar matrix, with significant value/sig 0.339 which is greater than 0.05 (alpha). The assumption is that the covariance in each group is homogeneous, so further calculations could be continued (fulfilled assumption). In addition, the result can be drawn by looking at the log values of the determinants of each group from log table. The log values of group determinants before e-government implementation was 1.953. However, the log values of determinant group after e-government implementation is 1.869 . The results of the two are relatively similar, indicating all variations of each group are equal.

By using the entry/remove method, results indicate that there are two variables having sig which is below 0.05 . Variable on the quantity of work is 0,000 . It is far from 0.05 . Thus, from three variables, there are only two variables which are significant. In other words, the quantity of work and on time working schedule are the most influential variables, bringing changes to employee performance before and after e-government implementation. Furthermore, the number of Wilk`s Lambda is similar to the last digit of step 2 in making the 
discriminant model. The Chi-Square number at 68,555 with a high level of significance shows a clear distinction between the two Groups (before e-government implementation and after the implementation). This means that there is a significant difference between employee performance before e-government implementation and after the implementation.

\section{DISCUSSION OF RESULTS}

Referring to research findings, in order to see whether there is significant difference between employee performance before and after e-government implementation at the Local Board for Finance and Asset Management at Tanggamus Regency, the situation can be explained through three dimensions of employee performance as follows: first is the comparison of work quantity. Based on data analysis, it can be seen through Enter and Remove variables. There was an elimination of variables which have no significant effect/influence. It is seen that the variable of working quantity has the highest statistic number at 97.035 , with significance number at 0.000 , meaning the significant number is far below 0.05 , proving that there is a significant different between the quantity of work before and after the implementation of E-Government.

Moreover, there is a significant difference in the quantity of work after and before egovernment implementation. Findings show that the significant impact on quantity of work leads to the positive outcome on employees' performance, such as the achievement of job targets, increasing the results of work standards, the achievement of work programs that have been set out, alleviation of the workload, increased output or the results of jobs and several outcome related to the quantity of work. E-government implementation in this case refers the use of an application called the Local Information System (Sistem Informasi Daerah/SIMDA) on Finance which is able to improve good results and job performance in the Fund Disbursement Order (SP2D) since the application of finance includes data processing, management system and electronic working process. Thus, the purpose of e-government implementation in order to improve the quality of service in a more effective and efficient can be achieved.

Second is the comparison of working quality. From the frequency distribution analysis, it is found that there is the difference between quality of work before and after e-government implementation. However, the analysis has not been able to prove whether there is a significant difference in the quality dimensions of employees' works. To find out this, the strategy was to use Enter/Remove variables, showing there is no significant effect on the quality of work. From the predetermined hypothesis, it has been found that there is no significant difference between the quality of work before and after e-government implementation, meaning that the quality of work becomes a variable that is not examined further. The reason is because the quality of work does not meet the assumption of discriminant (a removed variable).

Quality of work does not give a significant effect or change after e-government implementation. There are several reasons for that: 1) the definition of E-Government which is the electronic-based government and in this case, local government of Tanggamus using an application called SIMDA Finance to change a system of financial administration. Certainly, the readiness of the system is not the only successful determinant factor of EGovernment since the human resource is also an inseparable factor in this case. So the failed of the implementation of E-Government in the purpose of improving employees' performance in the sense of quality of work is due to lack of preparedness of employees at the Local Board for Finance and Asset Management at Tanggamus Regency where previously they used manual system, and turned into electronic systems. This unpreparedness certainly affects the quality of employees because employees as the operator or users of the application system have not understood and do not have a good skill associated with the software connected to nature of the work.

Third is the comparison of on time working schedule. For the entry/remove method, two variables can be included in the discriminant model. They are the quantity of work and on time working schedule. The variable of on time working schedule has the value at sig of $F$ 
which is below 0.05 , i.e. 0.004 . This means that the variable is to be removed. Furthermore, Wilks' Lambda test of on time working schedule is also included with a significance value of 0,000 . This means that the variable of on time working schedule is one of the variables that have significant differences between the two groups. There has been a significant change in the variable of on time working schedule after e-government implementation, comparing with the score before the implementation. Findings show that the significant difference before and after e-government implementation leads to positive aspect of speed and timeliness in performing work in relation to procedures, increasing the level of attendance, achievement of work in more effective and efficient, and other aspects related to punctuality. This means that there has been a significant difference between punctuality before and after e-government implementation.

The use of the application, of course, aims to cut the bureaucracy processes which have been considered as too long in process. The use of e-government on financial application at Local Board for Finance and Asset Management at Tanggamus Regency results on the increase of the speed and timeliness in completing a job. In accordance with the benefits of e-government implementation in more efficient government, coordination can be done through the use of technology. So, the process of financial administration in Tanggamus Regency has been implemented in shorter time.

Fourth is the employee performance comparison. Findings suggest that e-government implementation turned out to have a significant influence in terms of improving employee performance. The policy on e-government implementation significantly increases the quantity of work and on time working schedule, although in terms of quality of work there is no significant difference. However, in general, there has been a noticeable change in performance improvement. Based on Presidential Instruction Number 3, Year 2003 on National Development Policy and Strategy, there are 4 levels of actions that must be done in e-government implementation. However, the Tanggamus Regency does not include the first stage which is the preparation of human resources. E-government implementation system is actually able to increase the performance employees in the Local Board for Finance and Asset Management at Tanggamus Regency. However, ideally, a system built with the aim of facilitating the work of users must also be balanced with the quality of human resources who will operate the system.

\section{CONCLUSION AND SUGGESTIONS}

This study concludes: first, there is a significant difference in the quantity of work before and after e-government implementation. This variable is the highest score of significance among other variables. Second, after e-government implementation, the quality of work is a variable that does not show significant difference in the performance of employees in the Local Board for Finance and Asset Management at Tanggamus Regency. Thus, quality of work does not include the variables studied (the removed variable). Third, there is a significant difference in the variable of on time working schedule before and after egovernment implementation. Fourth, of the three variables that have been studied, egovernment implementation gives a positive effect toward two variables namely the variable quantity of work and on time working schedule. Thus, the implementation of electronic system has a significant effect towards the positive on the performance of employees at the Local Board for Finance and Asset Management at Tanggamus Regency.

This study recommends several actions or efforts to improve the performance of employees in the Local Board for Finance and Asset Management at Tanggamus Regency. First, the system or application built aims to increase the quantity of work and the speed to complete a job but the application was not necessarily able to improve the quality of existing work therein. Thus, there is the need to set up Standard Operating Procedure (SOP) to meet the requirements of existing information technology systems. So, it is expected to be able to improve the quality of work. Second, to further improve the performance of employees in terms of quality of work, there is the need a kind of training and technical guidance on understanding and having skills on specific technicalities related to the use of SIMDA 
Finance applications and administration procedures in Local Board for Finance and Asset Management at Tanggamus Regency. Thus, it is expected that the quality of work of employees will increase and affects the performance of employees.

Third, results suggest that e-government implementation can give a significant influence on the performance of employees in Local Board for Finance and Asset Management at Tanggamus Regency. It is expected that e-government based system can be applied to other local agencies or bodies under the local government, especially, to institutions where government apparatus directly have responsibilities to provide public services.

\section{REFERENCES}

1. Adegboyega, Ojo, T. Janowski and E. Estevez. 2004. Determining Progress Towards egovernment: What are the core indicator. Proceeeding from ECEG2005, Amsterdam

2. Aimee, F., and Carol E., (2004), Aligning Priorities In Local Budgeting Processes. Journal of Public Budgeting, Accounting \& Financial Management. Boca Raton Summer 2004 Vol. 16 (2): 210.

3. Bakry S. 2003. Toward the development of a standard e-readiness assessment policy. International Journal of Network Management, Vol 13: $129-137$.

4. Basu, S. 2004. E-governance and Developing Countries: An Overview, International Review of Law Computers. Vol. 18 (1).

5. Burn, Janice \& Robins, Greg. 2003. Moving towards e-government: a case study of organizational change processes. Logistics Information Management 16(1): 25-35.

6. Creswell, J.W, 2014. Research Design: Qualitative, Quantitative and Mixed Methods Approaches, Fourth Edition. Los Angeles: SAGE Publication

7. Dharma, Surya. 2003. Manajemen Kinerja Falsafah Teori dan Penerapannya. Pustaka Pelajar. Yogyakarta.

8. Fagan, M. H. 2006. Exploring City, County and State E-Government Initiatives: An East Texas Perspective. Business Process Management Journal. 12 (1): 101-12.

9. Foley, P. and Alfonso, X. 2009. E-Government and the Transformation Agenda, Public Administration. Vol 87 (2): 371.

10. Gronlund, A. 2005. State of the Art in E-Gov Research: Surveying Conference Publications. International Journal of Electronic Government Research. Vol 1 (4):1 - 25.

11. Gronlund, A and Horan, T. A. 2005. Introducing E-Gov: History, Definitions, and Issues. Communications of the Association for Information Systems. Vol 15 (39): 713 - 29.

12. Koh, C.E. and Prybutok, V.R. 2003. The three ring model and development of an instrument for measuring dimensions of e-government functions. Journal of Computer Information Systems 43 (3): $34-39$.

13. Kraemer, K. and King, J. L. 2006. Information Technology and Administrative Reform: Will E-Government Be Different? International Journal of Electronic Government Research. Vol 2 (1): $1-20$.

14. Laye, K. and Lee. J. 2001. Developing fully functional e-government: A four stage model. Government Information Quarterly, 18: 122 - 136.

15. Meijer, A. 2007. Why Don't They Listen to Us? Reasserting the Role of ICT in Public Administration Information Polity. Vol 12 (4): 233.

16. Moon, M. Jae. 2000. The evolution of e-government among municipalities: rhetoric or reality? Public Administration Review 62(4): $424-433$.

17. Schuppan, T. 2009. E-Government in Developing Countries: Experiences from SubSaharan Africa. Government Information Quarterly. Vol 26 (1): 118.

18. Taylor, J. A. and Lips, A. M. B. 2008. The Citizen in the Information Polity: Exposing the Limits of the E-Government Paradigm. Information Polity, Vol 13 (3-4): 139.

19. Yildiz, M. 2007. E-Government Research: Reviewing the Literature, Limitations, and Ways Forward.Government Information Quarterly. 24: 3646. 